\title{
Nominations Accepted for the 2019 APSA Awards
}

$\mathrm{S}$ ubmit your nominations for the APSA dissertation, book, paper and article, and career awards, which will be presented at the 2019 APSA Annual Meeting in Washington, DC. The deadline for submission will be in February 2019. For more information, visit www.apsanet.org/awards. The 2019 awards are listed below.

\section{GOODNOW AWARD}

The Frank J. Goodnow Award is for distinguished service to the profession and the American Political Science Association, not necessarily a career of scholarship. This service may be by individuals, groups, or public and private organizations who have played a role in the development of the political science profession and the building of the association.

\section{CAREER AWARDS}

Bestowed for significant achievements related to political science.

\section{APSA Distinguished Teaching Award To honor outstanding contributions to undergraduate and/or graduate teaching of political science at two- and four-year institutions. The award recognizes con- tributions that have made a significant impact on the manner in which political science is taught.}

\section{John Gaus Distinguished Award and Lectureship \\ Honors the recipient's lifetime of exem- plary scholarship in political science and public administration.}

\section{Hubert H. Humphrey Award}

In recognition of notable public service by a political scientist.

\section{Carey McWilliams Award}

Recognizes a major journalistic contribution to our understanding of politics.

\section{Benjamin E. Lippincott Award}

For exceptional work by a living political theorist that is still considered significant after a time span of at least 15 years since the original publication (supported by the University of Minnesota).

\section{Charles Merriam Award}

For a person whose published work and career represent a significant contribution to the art of government through the application of social science research.

\section{Ithiel de Sola Pool Award}

For a scholar selected to present a lecture exploring the implications of research on issues of politics in a range of scholarship pursued by Ithiel de Sola Pool.

\section{Hanes Walton Jr. Career Award}

For a political scientist whose lifetime of distinguished scholarship "has made significant contributions to our understanding of racial and ethnic politics and illuminates the conditions under which diversity and intergroup tolerance thrive in democratic societies."

\section{DISSERTATION AWARDS}

Departments are invited to submit dissertations that have been completed in the past two academic years.

\section{Gabriel A. Almond Award}

In the field of comparative politics.

\section{William Anderson Award}

In the field of federalism or intergovernmental relations, state, or local politics.

\section{Edward S. Corwin Award}

In the field of public law.

\section{Harold D. Lasswell Award}

In the field of public policy.

\section{Merze Tate Award}

In the field of international relations, law, and politics.

\section{E.E. Schattschneider Award}

In the field of American government.

\section{Leo Strauss Award}

In the field of political philosophy.

\section{Leonard D. White}

In the field of public administration.

\section{BOOK AWARDS}

Books published in 2018 may be nominated by individuals or publishers.

\section{Ralph J. Bunche Award}

For the best scholarly work in political science that explores the phenomenon of ethnic and cultural pluralism.

\section{Robert A. Dahl Award}

Awarded to an untenured scholar who has produced scholarship of the highest quality on the subject of democracy, including books, papers, and articles.

\section{Theodore J. Lowi Award}

For the best first book in any field of political science, showing promise of having a substantive impact on the overall discipline, regardless of method, specific focus of inquiry or approach to subject.

\section{Gladys M. Kammerer Award}

For the best political science publication in the field of US national policy.

\section{Victoria Schuck Award}

For the best book published on women and politics.

\section{Woodrow Wilson Foundation Award}

For the best book published in the United States in the field of government, politics, or international affairs.

\section{PAPER AND ARTICLE AWARDS}

Papers and articles published in 2018 may be nominated by individuals or publishers.

\section{Franklin L. Burdette/Pi Sigma Alpha Award}

For the best paper presented at the previous APSA Annual Meeting.

\section{Robert A. Dahl Award}

For an untenured scholar who has produced scholarship of the highest quality on the subject of democracy, including books, papers, and articles.

\section{Heinz Eulau Award}

For the best articles published in the APSR and Perspectives on Politics during the previous year. 